\title{
The Potency of Anadara nodifera Shell as Natural Testosterone Booster for Male Canary (Seriunus canaria)
}

\author{
Pudji Astuti ${ }^{*}$, Muhammad Naufal Prayitno Putra ${ }^{2}$, Muhammad Fariz Ash Shiddiq ${ }^{2}$, Rizki Fitrawan Yuneldi ${ }^{3}$, Claude \\ Mona Airin', Sarmin' \\ 'Department of Physiology, Faculty of Veterinary Medicine, Universitas Gadjah Mada, Yogyakarta, Indonesia \\ ${ }^{2}$ Student of Veterinary Profession Programme, Faculty of Veterinary Medicine, Universitas Gadjah Mada, Yogyakarta, Indonesia \\ ${ }^{3}$ Doctoral candidate, Sain Veteriner Postgraduate Programme, Faculty of Veterinary Medicine, Universitas Gadjah Mada, Yogyakarta, \\ Indonesia
}

ARTICLE INFO

Article history:

Received August 26, 2021

Received in revised form September 23, 2021

Accepted October 11, 2021

\section{KEYWORDS:}

CYP19 aromatase,

Shell of Anadara nodifera,

Testosterone,

Zinc

\begin{abstract}
Anadara clam shell contains high Zinc. This microelement is recognised as acting natural aromatase blocker (NAB) that capable of boosting testosterone level. The aim of this study was to evaluates the testosterone level of Canaries following Anadara nodifera administration. Adult male Canaries $(n=27)$ were group into 3 with 9 repetition of each i.e T0 [control, was given by Carboxymethyl Cellulose Sodium (Na-CMC)], T1 (Zinc Sulphate $0.013 \mathrm{mg} / 30 \mathrm{~g} \mathrm{BW}$ ), and T2 (NAB 0.3 mg/30 g BW). The T2 treatment was NAB or shell powder of Anadara nodifera which was diluted 1:1 in Na-CMC. The birds were treated orally for 21 days. The complete blood cell count was performed in a haemo analyser except the erythrocyte was calculated manually in the Improved Neubauer counting chamber. Testosterone level was measured in ELISA. Subsequently gen CYP19 aromatase in syrinx, brain and testis were identified employing IHC and descriptively analysed. The result indicated significant elevated level of testosterone $(p<0.05)$. The expression of CYP19 aromatase receptor was depressed in syrinx, brain and testis. However there was no significant changes on the blood profile $(p>0.05)$. To conclude, Anadara nodifera at $0.3 \mathrm{mg} / 30 \mathrm{~g} \mathrm{BW}$ was capable of acting as NAB to promote testosterone level. This was confirmed by the reduction of CYP19 aromatase gene receptors in syrinx, brain and testis. However NAB treatment was not significantly affecting routine blood profile.
\end{abstract}

\section{Introduction}

Anadara is one of highly nutritious shellfish, have wide acceptance in the society. In Indonesia, the harvest of Anadara nodifera is abundance and, the shells is becoming waste since only the meat is valuable. Shellfish is well known to increase testosterone levels in humans (Zhang et al. 2021). To add, Astuti et al. (2019) have reported the application of Anadara granosa shell to increase the level of testosterone in rat. However the hypothetical potency of Anadara nodifera has not yet explored.

Testosterone is a vital male hormone. It controls voice, growth, muscle strength, spermatogenesis, and sex drive (Astuti et al. 2006, 2019; Josiak et al. 2014; Ko et al. 2021; Yuneldi et al. 2021a, 2021b,

* Corresponding Author

E-mail Address: pastuti2@ugm.ac.id 2021c, 2021d). Common practice of injecting anabolic hormones such as testosterone in male birds is proposed to maintain the performance. However constant low dose injection of synthetic testosterone may induce a down-regulation mechanism, a drastic reduction of testosterone level. During downregulation, the amount of testosterone receptor is decreased leading to poor voice quality and in severe cases the birds may lose voice (Pomara et al. 2016). The testosterone hormone in the body is naturally converted into oestrogen by an aromatase enzyme causing a challenge in maintaining a steady high level of testosterone (Çinar et al. 2017). However the conversion could be depress by aromatase blocker. The inhibition of testosterone to oestrogen will maintain high levels of testosterone in the body then provide sufficient supply for body-effects related to testosterone. Therefore, a natural agent capable of acting as a natural aromatase blocker is essential 
to prevent conversion of testosterone to estradiol (Astuti et al. 2018, 2019). Astuti et al. (2019) found $0.18 \mathrm{mg} / 200 \mathrm{~g}$ BW of Anadara granosa shell powder was able to increase testosterone hormone in rats. In Aves, the administration at $0.9 \mathrm{mg} / \mathrm{kg}$ BW have improved the voice quality of Pelung chickens (Yuneldi et al. 2012d) also boost the testosterone level in layers (Yuneldi et al. 2012a). These finding unveil the possibility to improve the voice quality of singing birds.

Synthetic aromatase blocker have been identified and applied i.e. Fadrozole for Pimephales promelas fish (Saari et al. 2017); Anastrozole, Letrozole (Linardi et al. 2017), also Exemestane for aging broiler rooster (Bazyar et al. 2019). However, long term administration of synthetic substance may lead to adverse reactions, also raising issues from drug residue in certain organs.

Astuti et al. (2019) have reported reduction expression of aromatase CYP19 receptors in the brain following Anadara granosa powder shell treatment rat. Here, akin genus of Anadara, the Anadara nodifera, was evaluated as aromatase blocker CYP19 notably in syrinx as voice controller in canary birds. The Anadara nodifera shell is estimated to contain high Zinc which may act as aromatase blocker.

This research was intended to identify and evaluate natural aromatase blockers which are capable of improving the sound quality of male canaries, riskless, obtainable, and inexpensive. Also, to improve the utilisation of Anadara nodifera shell which is considered waste.

\section{Materials and Methods}

\subsection{Ethical Clearance}

The research procedures performed in this study were in accordance with the Integrated Research and Testing Laboratory (LPPT) UGM Research Ethic Committee Number: 00021/04/LPPT/V/2019.

\subsection{Preparation of Anadara nodifera Shell Powder}

The clams was collected from beaches in Gunung Kidul, Daerah Istimewa Yogyakarta, Indonesia. Initially the clams was boiled then the shells was separated from the meat. Afterward the shells was scrubbed and sundry for 1-2 days. The shells then boiled with $\mathrm{NaOH} 1 \mathrm{~N}$ at $50^{\circ} \mathrm{C}$ for 3 hours and neutralised by washing. Subsequently the shells were dried in the oven at $120^{\circ} \mathrm{C}$ for 6 to 8 hours then grinded to powder.

\subsection{Experimental Design}

This experiment was employing 27 adult male Canary birds with approximate weight of $30 \mathrm{~g}$. The animals were divided into 3 groups with 9 repetition each i.e T0: received Carboxymethyl Cellulose Sodium (Na-CMC) as control, T1: received Zinc Sulphate $0.013 \mathrm{mg} / 30 \mathrm{~g} \mathrm{BW}$, and T2: received NAB $0.3 \mathrm{mg} / 30 \mathrm{~g}$ BW. Treatment T2 was NAB or shell powder of Anadara nodifera was diluted 1:1 in Na-CMC. Each birds was treated orally for 21 days (Astuti et al. 2020; Yuneldi et al. 2021a).

\subsection{Blood Withdrawn and Organ Collection}

Prior bleeding the birds were sedated by intramuscular route using combination of Ketamine and Xylazine at $25-40 \mathrm{mg} / \mathrm{kg}$ and $5-50 \mathrm{mg} /$ $\mathrm{kg}$ respectively. The blood then withdrawn via intracardial and contained in Ethylen Diamine Tetra Acetaticacid (EDTA) tube.

Subsequently the birds were euthanised by separating the head and the body using sharp knife according to IOWA University, 2016 (Bird Euthanasia Procedure, Comparative Medicine and Animal Resources Centre, Iowa State University, 2016).

\subsection{Complete Blood Test Count}

The collected blood was processed for complete blood count including haemoglobin ( $\mathrm{Hb}$ ) and differential leucocytes in haemo analyser. Since in Aves, the red blood cells are nucleated (Beaufrère et al. 2013), the haemo analyser could not distinguish between erythrocytes and leukocytes. Therefore the erythrocyte count was done manually employing an improved Neubauer tube.According Mohammed etal. (2021) and Onyishi et al.(2017) that mean corpuscular volume (MCV), mean corpuscle haemoglobin ( $\mathrm{MCH})$ and mean corpuscle haemoglobin concentration (MCHC) were obtained from the red blood cell (RBC) count, packed cell volume (PCV) and haemoglobin $\mathrm{Hb}$ ) concentration through the following formula:

$$
\begin{aligned}
\mathrm{MCH}(\mathrm{pg}) & =\frac{\mathrm{Hb}}{\mathrm{RBC}} \times 10 \\
\operatorname{MVC}(\mathrm{fL}) & =\frac{\mathrm{PVC}}{\mathrm{RBC}} \times 10 \\
\mathrm{MCHC}(\mathrm{g} / \mathrm{dL}) & =\frac{\mathrm{Hb}}{\mathrm{PVC}} \times 10
\end{aligned}
$$




\subsection{Testosterone Level Measurement}

The level of testosterone was measured from blood plasma employing ELISA (Calbiotech). The blood was centrifuged at 3,000 rpm for 20 minutes then assay. The ELISA was performed as per manufacturer direction. The steps for measured testosterone levels were $50 \mu \mathrm{l}$ standard solution and samples were poured into wells and then $100 \mu$ l enzyme conjugate reagent was added, $50 \mu$ Biotin reagent was added into each well. Swing the microplate gently for 2030 seconds to mix the reagents and incubated for 60 minutes, at room temperature. Next, the wells were rinsed 3 times using $300 \mu$ wash buffer. Subsequently, 100-300 $\mu \mathrm{l}$ TMB substrate reagent was added to the wells, while the microplate was covered and incubated for 30 minutes. Then, $50 \mu l$ stop solution was added to the wells and absorbance was read using ELISA Reader or Microplate Reader (ZENIX-320) with the absorbance wave of $450 \mathrm{~nm}$ for 15 minutes (Yuneldi et al. 2021d).

\subsection{Immunohistochemical Staining Methods}

The syrinx, brain and testis were fixated in PBS$10 \%$ formalin for $18-24$ hours followed by paraffin embedding. The paraffin block was sectioned at $4 \mu \mathrm{m}$ thick then mount on coated poly-L-Lysine (Sigma ${ }^{\circledR}$ ) slide glass, deparaffinated and rehydrated. Following probing with aromatase CYP19 (C-16) SC-14245 monoclonal antibody (Santa Cruz Biotechnology) at $1: 100$, the section was chromogenic stained with biotin secondary antibody at 1:100 anti mouse, then labelled with streptavidin-biotin peroxidase and mounted with Canada balsam after dehydrated. Brown stained cells indicated the expression of CYP19 aromatase (Astuti et al. 2019).

\subsection{Statistical Analysis}

The statistical analysis of the available parameters were employing one way ANOVA with 95\% CI ( $\alpha=$
0.05). If significant distinction found the test was proceed to Tukey HSD. The analysis was performed in SPSS v.15 (Yuneldi et al. 2018, 2021c).

\section{Results}

\subsection{Description of Complete Blood Count}

Complete blood count examination plays important role in diagnose a disease since noticeable changes may occur prior clinical signs observed. There was no significant changes $(p>0.05)$ in the complete blood count (Table 1). This indicated the bird's health was not affecting by the treatment.

\subsection{Testosterone Hormone}

The testosterone hormone analysis showed significant changes of $\mathrm{T} 2$ (NAB) compared to T0 (Control) and T1 (Zinc Sulphate) $(\mathrm{p}<0.05)$. Although the hormone level in T1 (Zinc Sulphate) was elevating in comparison to T0 (Control) however it was not significantly different ( $p>0.05$ ) (Table 2 ). This finding showed the $\mathrm{Zn}$ contained in Anadara nodifera shell powder was able to boost testosterone level in male Canaries.

\subsection{The Expression of CYP19 Aromatase in Syrinx, Brain, and Testis after Treatment}

The immunohistochemistry staining of syrinx, brain and testis signified the derivation of Сyp19 aromatase expression of T0 (Control), treatment group T1 (Zinc Sulphate) and T2 (NAB). However the Cyp19 aromatase expression of $\mathrm{T} 0$ and $\mathrm{T} 1$ was detectable in contrary to T2 (NAB). This condition indicate the aromatase enzyme was greatly supressed consequently reduced the testosterone conversion into oestrogen (Figure 1C). Similar explanation also visible in brain, the expression of Cyp19 aromatase gene at T0 was highly distinct then gradually

Table 1. The haemoglobin, hematocrit, erythrocytes, leukocytes, MCV, MCH, and MCHC measurement of the male Canary

\begin{tabular}{llcl}
\hline \multirow{2}{*}{ Variables } & \multicolumn{3}{c}{ Average \pm SD } \\
\cline { 2 - 4 } & T0 (control) & T1 (Zinc sulphate) & T2 (NAB) \\
\hline Haemoglobin (gr/dL) & $12.13 \pm 0.52^{\mathrm{a}}$ & $12.07 \pm 0.79^{\mathrm{a}}$ & $12.47 \pm 0.70^{\mathrm{a}}$ \\
Hematocrit $(\%)$ & $50.33 \pm 9.26^{\mathrm{a}}$ & $44.33 \pm 3.90^{\mathrm{a}}$ & $43.67 \pm 2.78^{\mathrm{a}}$ \\
Erythrocyte (million/Ul) & $3.61 \pm 0.74^{\mathrm{a}}$ & $3.91 \pm 0.54^{\mathrm{a}}$ & $3.33 \pm 0.43^{\mathrm{a}}$ \\
Leukocyte (thousand/mm 3 ) & $3.60 \pm 0.22^{\mathrm{a}}$ & $3.33 \pm 0.27^{\mathrm{a}}$ & $3.30 \pm 0.38^{\mathrm{a}}$ \\
MCV $(\mathrm{fL})$ & $139.88 \pm 24.69^{\mathrm{a}}$ & $134.32 \pm 19.92^{\mathrm{a}}$ & $133.50 \pm 14.31^{\mathrm{a}}$ \\
MCH (pg) & $34.45 \pm 4.97^{\mathrm{a}}$ & $31.64 \pm 6.77^{\mathrm{a}}$ & $37.95 \pm 5.29^{\mathrm{a}}$ \\
MCHC (g/dl) & $24.83 \pm 4.59^{\mathrm{a}}$ & $27.56 \pm 4.20^{\mathrm{a}}$ & $28.73 \pm 3.41^{\mathrm{a}}$
\end{tabular}

a,b Different superscripts in the same row indicate significant differences $(\mathrm{p}<0.05)$ 
Table 2. Testosterone level of male Canary after 21 days of Treatment treatment

\section{T0 (Control)}

T1 (Zinc sulphate)

T2 (NAB)

a, bifferent superscripts in the same column indicate significant differences $(\mathrm{p}<0.05)$ decreased to T1 and finally invisible at T2 (Figure 2C). Comparable to brain, the Cyp19 aromatase gene in $\mathrm{T} 0$ testis also distinctly expressed and at $\mathrm{T} 1$ and $\mathrm{T} 2$ the expression was gradually imperceptible (Figure 3C).

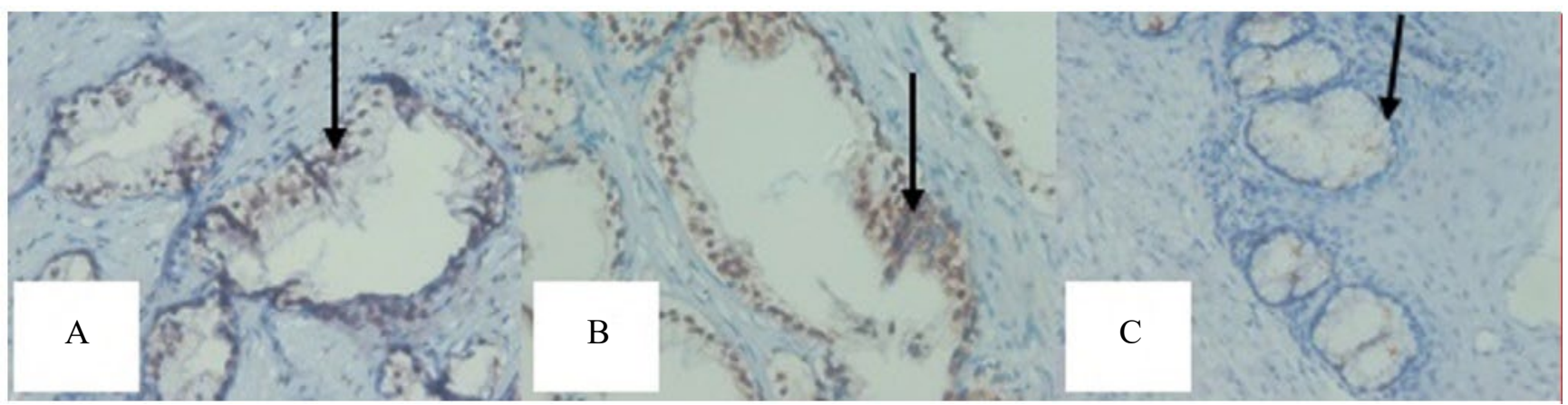

Figure 1. (A) The aromatase gene Cyp19 is strongly expressed in T0 (Control), (B) Cyp19 gene in T1 (Zinc sulphate) is modestly expressed, (C) the aromatase Cyp19 gene in T2 (NAB) is not expressed. The voice controller organ Syrinx is indicated by arrow. Magnification: $400 \mathrm{x}$

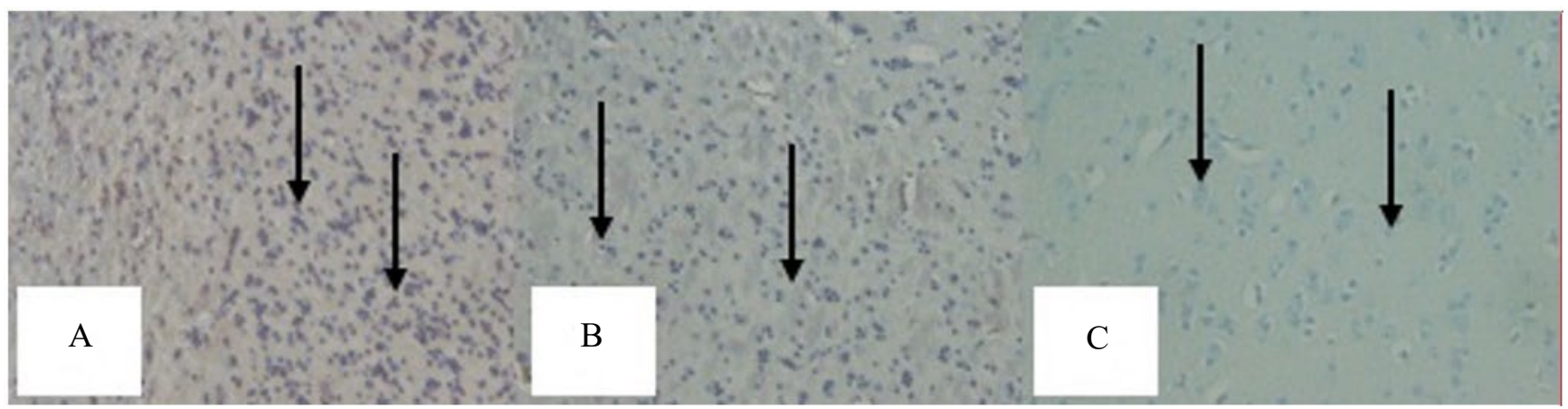

Figure 2. (A) The aromatase Cyp19 receptor in T0 (Control) is strongly expressed (brown colour), (B) the aromatase Cyp19 receptor in T1 (Zinc sulphate) is lightly expressed, (C) the aromatase Cyp19 receptor in T2 (NAB) is not expressed. The brain sex-drive organ of male Canary is indicated by brown colour (arrow). Magnification: 400x

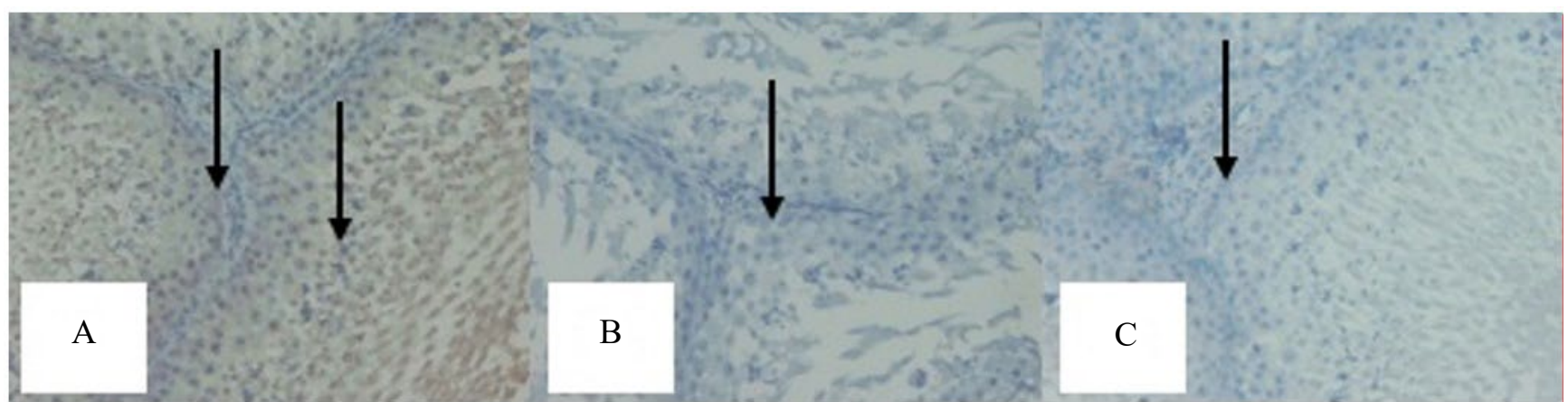

Figure 3. (A) The aromatase Cyp19 receptor in T0 (Control) is strongly expressed (brown colour), (B) The aromatase Cyp19 receptor in T1 (Zinc sulphate) is lightly expressed, (C) the aromatase Cyp19 receptor in T2 (NAB) is not expressed. The testis on male Canary. Magnification: 400x 


\section{Discussion}

\subsection{Complete Blood Test Description Post Treatment}

Treatment with Anadara shell powder was not generate adverse reaction in the complete blood test count of the male canary. The average PCV value in Aves is 40\% (Bickford 2007). According to Nwogor et al. (2015) and Nwogor et al. (2020) reported that normal ranged from $26.0-45.2 \%$. This is in accordance with the findings of Zeryehun et al. (2017) which also revealed that normal PCV in avian species is $35-50 \%$. El-Hendy et al. (2001) reported Zn deficiency have adverse effect to growth rate, specific organ weight, haematology parameter, $\mathrm{Zn}, \mathrm{Cu}$, and Fe serum level in rat. Further description by Darwish et al. (2021) that level of Zinc was related to the absorbance of iron in blood cells. In food, Zinc is highly contained in oyster (Kaur et al. 2014). The shell of Anadara granosa is containing macrominerals i.e. $\mathrm{Zn}, \mathrm{Mg}$, $\mathrm{Ca}, \mathrm{Na}, \mathrm{Fe}$, and $\mathrm{K}$ and has the highest $\mathrm{Zn}$ contents compared to $P$ viridis and $T$ telecospium (Astuti et al. 2019). However excessive Zinc could lead to Copper deficiency since zinc is able to competitively inhibit copper attachment in the gastrointestinal tract. Metallothionein upregulation gene expression plays an important role in this phenomenon (Kaur et al. 2014). Macromineral Zinc is found in Anadara nodifera and serve as an aromatase blocker (Sankako et al. 2012). In addition, Oyster (Ostrea edulis Linnaeus) is rich in zinc and copper complexes (Coombs 1974; Wang and Wang 2014).

\subsection{Testosterone Level after Treatment}

The $\mathrm{Zn}$ content in clam shell powder plays an important role as an aromatase blocker to inhibit the aromatase enzyme from converting testosterone into oestrogen (Astuti et al. 2019; Yuneldi et al. 2021a; Yuneldi et al. 2021d). Enzyme of aromatase is a cytochrome P450 enzyme (CYP19A1 isoform) action which catalyse the conversion of androgens to oestrogens. The aromatase inhibitors (AI) application in short men was beneficial by increasing height (Linardi et al. 2017). Zinc contained in oyster meat is able to boost testosterone level in human (Brenowitz 2013). Aromatization is notorious to play an important role in the testosterone signalling pathway of brain. Furthermore, oestrogen metabolites together with testosterone regulate and activate masculine neural circuits (Roselli 2007).
The combination of Zinc and Se for treatment is found ineffective since those elements act antagonistically. A similar antagonistic mechanism also recognised in cooper $(\mathrm{Pb})$ and $\mathrm{Zn}$ as described by Kaur et al. (2014): the supplementation of cooper increased Zinc conjugation to large molecules and depleted the ratio of zinc coupled with smaller molecules hence manifest the antagonism between copper and zinc. Excessive zinc in the body may lead to copper deficiency through competitive inhibition to bind in the gastrointestinal tract. The gene expression of metallothionein upregulation may be responsible in this phenomenon. On contrary, zinc deficiency results in excessive conversion of testosterone into oestrogen (Sauer et al. 2016). Zinc acts as an inhibitor aromatase enzyme which convert oestradiol to testosterone. Zinc is transferred from and out of the cells by transport protein (Çınar et al. 2017).

$\mathrm{T} 1$ (Zinc sulphate) treatment as aromatase blocker was not showed significant result ( $p>0.05$ ), however the Zinc contained in oyster shell powder or treatment T2 (NAB) was greatly affected the level of testosterone $(\mathrm{p}<0.05)$ including the Cyp19 aromatase expression (Table 2, Figure 1, 2, and 3). Similar description also observed in rat (Astuti et al. 2019); rooster layer (Yuneldi et al. 2021a) and Bangkok chicken (Astuti et al. 2021). Souza et al. (2021) have reported during the conversion of testosterone to oestrogen, the aromatase enzyme (Сyp19) acts by producing a C-19 gem-diol. Subsequently, the A-ring aromatization is provided by the abstraction of $1 \beta$-Hydrogen and electron transfer also deprivation of the molecular structure to accomplish a single substitution.

\subsection{The Expression of CYP19 Aromatase in Syrinx, Brain, and Testis Post Treatment}

Immunohistochemical staining showed a decrease in the aromatase receptor Cyp19 in the syrinx, brain, and testis, although the decrease was not distinctive as in the NAB treatment (Figure $1 \mathrm{C}, 2 \mathrm{C}$, and $3 \mathrm{C}$ ). The immunohistochemistry staining demonstrated the weak expression of Cyp19 aromatase receptors in syrinx, brain and testis if compared to T0 (Control) (Figure 1, 2, and 3). However this finding was contrary to Daragó et al. (2020) which indicated the elevation of Testosterone level in Wistar rat following Zinc treatment, and androgen receptor (Çınar et al. 2017). The aromatase inhibitors are classified into steroid/non-steroidal, reversible (ionic bonds) and irreversible (suicide inhibitors, 
covalent bonds) according to the generation. Steroid aromatase inhibitors are androstenedione analogues with a pseudo-compound mechanism that binds irreversibly to the androgen attachment site of the enzyme, while non-steroidal aromatase inhibitors show their function by binding via heme bonds to the cytochrome P450 enzyme (Permadi 2013; Souza et al. 2021).

Previous research has showed the administration of a synthetic aromatase blocker, Letrozole, was capable of reducing peripheral oestradiol levels in non-human primates (Gervais et al. 2019) also assumed to treat inflammation (Fusi et al. 2014). Letrozole and Anastrozole are thought to be able to bind to the heme group of cytochrome P450 reversibly. In fact, aromatase blockers may act as inducers or inhibitors of cytochrome P450 enzymes. Since it is non-steroidal, it is estimated that zinc contained in shellfish performs by linking itself with its lone pair of electrons carried by the azole ring heteroatom, then interacting with the Fe atom of the porphyrin ring in the aromatase binding site, causing enzyme inactivation (Prachayasittikul et al. 2014). Further explanation is the complexation of ions and metallic bonds occurs dynamically and is reversible. The metabolism of aromatase blockers has involved three chemical processes, i.e hydroxylation, $\mathrm{N}$-dealkylation and glucuronidation (Linardi et al. 2017).

Brenowitz (2013) reported that testosterone is able to increase the synthesis of brain-derived neurotrophic factor (BDNF) in HVC, then BDNF protein will be released into postsynaptic cells in the RA nucleus where it has trophic. This is also supported by the documentation of capability Anadara granosa shell to increase the singing frequency of Canaries and Pelung chickens (Astuti et al. 2020; Yuneldi et al. 2021d). It is then assumed that Anadara nodifera also capable of increasing the frequency and sound quality of male canaries. However, the Zinc as an aromatase blocker nonetheless requires further research to administer as a single administration or a combination with other macromolecules, or incorporated in a compound.

Our results showed the application of Anadara nodifera was able to increase the testosterone levels, to reduce the expression of the CYP19 aromatase receptor in the brain, syrinx, testis, and was not affecting the complete blood counting. To conclude, the treatment T2 was NAB $0.3 \mathrm{mg} / 30 \mathrm{~g}$ BW (shell powder of Anadara nodifera was diluted $1: 1$ in NaCMC) could act as a natural aromatase blocker to increase testosterone levels. This was demonstrated in the reduction of the CYP19 aromatase receptor expression. Nevertheless, no evidence was found
NAB treatment could generate significant effects to the complete blood count.

\section{Acknowledgements}

This work is supported by the Thesis Recognition student project (RTA project). We would like to thank the Research Directorate of Universitas Gadjah Mada, Indonesia.

\section{References}

Astuti, P., Yusuf, T.L., Hayes, E., Maheshwari, H., Sjahfirdi, L., Sajuthi, D., 2006. Pola diurnal metabolit testosteron dan kortisol di dalam feses Owa Jawa (Hylobates moloch) di Penangkaran. Hayati J. Biosci. 13, 69-72. https://doi.org/10.1016/S1978-3019(16)30384-9

Astuti P., Airin, C.M., Nururrozi, A., Harimurti, S., 2018. PCS-8 oyster shell powder as alternatives macromineral for synthetic testosterone. Hamera Zoa. 2012, 164-165.

Astuti P., Airin, C.M., Sarmin, S., Nururrozi, A., Harimurti, S., 2019. Effect of shell as natural testosterone boosters in Sprague Dawley rats. Vet. World. 12, 1677-1681. https://doi.org/10.14202/vetworld.2019.1677-1681

Astuti, P., Airin, C.M., Nurrurozi, A., Aidi, R., Hana, A., Hadi, S., Harimurti, H., 2020. Potential natural aromatase blockers on enhance the frequency and sound quality of male Canaries. E3S Web of Conferences. 151, 01024. https://doi.org/10.1051/e3sconf/202015101024

Astuti, P., Airin, C.M., Hana, R.R.A., Yuneldi, R.F., Sarmin, 2021. The effect of natural aromatase blockers on the testicle weight, size of wattle and histopatological of testis in Bangkok. BIO Web of Conferences. 33, 06002. https://doi.org/10.1051/bioconf/20213306002

Bazyar, M., Sharafi, M., Shahverdi, A., 2019. Changes in seminal parameters and hormonal profile with use of aromatase inhibitor in management of aging broiler breeder roosters. Poult. Sci. 98, 6100-6107. https:// doi.org/10.3382/ps/pez325

Beaufrère, H., Ammersbach, M., Tully, T.N., 2013. Complete blood cell count in psittaciformes by using highthroughput image cytometry: A pilot study. J. Avian Med. Surg. 3, 211-217. https://doi.org/10.1647/10826742-27.3.211

Bickford, D., 2007. Identifying avian blood cells. Vet Technician. $28,490$.

Brenowitz, E.A., 2013. Testosterone and BDNF interactions in the avian song control system. Neurosci. 239, 115-123. https://doi.org/10.1016/j.neuroscience.2012.09.023

Çınar, V., Talaghir, L.G., Akbulut, T., Turgut, M., Sarıkaya, M. 2017. The effects of the zinc supplementation and weight trainings on the testosterone levels. Hum. Sport Med. 17, 58-63. https://doi.org/10.14529/hsm170407

Coombs, T.L., 1974. The nature of zinc and copper complexes in the oyster Ostrea edulis. Mar Biol. 28,1-10. https:// doi.org/10.1007/BF00389111

Daragó, A., Klimczak, M., Stragierowicz, J., Kilanowicz, A., Stasikowska-Kanicka, O., 2020. The effect of zinc, selenium, and their combined supplementation on androgen receptor protein expression in the prostate lobes and serum steroid hormone concentrations of wistar rats. Nutr. 12, 1-13. https://doi.org/10.3390/ nu12010153

Darwish, A.M.G., Soliman, T.N., Elhendy, H.A., El-Kholy, W.M. 2021. Nano-encapsulated iron and folic acidfortified functional yogurt enhance anemia in albino rats. Front. Nutr. 8, 1-23. https://doi.org/10.3389/ fnut.2021.654624 
Fusi, C. Materazzi, S., Benemei, S., Coppi, E., Trevisan, G. Marone, IM., Minocci, D., De Logu, F., Tuccinardi, T., Di Tommaso, M.R., Susini, T., Moneti, G., Pieraccini, G., Geppetti, P., Nassini, R.., 2014. Steroidal and nonsteroidal third-generation aromatase inhibitors induce pain-like symptoms via TRPA1. Nat. Commun. 5, 1-14. https://doi.org/10.1038/ncomms6736

Gervais, N.J., Remage-Healey, L., Starrett, J.R., Pollak, D.J., Mong, J.A., Lacreuse, A., 2019. Adverse effects of aromatase inhibition on the brain and behavior in a nonhuman primate. J. Neurosci.39,918-928. https:// doi.org/10.1523/JNEUROSCI.0353-18.2018

El Hendy, H.A., Yousef, M.I. and Abo El-Naga, N.I., 2001. Effect of dietary zinc deficiency on hematological and biochemical parameters and concentrations of zinc, copper, and iron in growing rats. Toxicol. 167, 163-170. https://doi.org/10.1016/S0300-483X(01)00373-0

Josiak, K., Jankowska, E.A., Piepoli, M.F., Banasiak, W., Ponikowski, P., 2014. Skeletal myopathy in patients with chronic heart failure: significance of anabolicandrogenic hormones. J. Cachexia Sarcopenia Muscle. 5, 287-296. https://doi.org/10.1007/s13539-0140152-Z

Kaur, K., Gupta, R., Saraf, S.A., Saraf, S.K., 2014. Zinc: the metal of life. Compr. Rev. Food Sci. Food Saf. 13, 358-376. https://doi.org/10.1111/1541-4337.12067

Ko, M.C., Frankl-Vilches, C., Bakker, A., Gahr, M. 2021. The gene expression profile of the song control nucleus hvc shows sex specificity, hormone responsiveness, and species specificity among songbirds. Fron. Neurosci. 15, 1-14. https://doi.org/10.3389/fnins.2021.680530

Linardi, A., Damiani, D., Longui, C.A., 2017. The use of aromatase inhibitors in boys with short stature: what to know before prescribing?. Arch Endocrinol Metabolism 61, 391-397. https://doi.org/10.1590/23593997000000284

Mohammed, A., Nuhu, S.H., Umar, S., Umar, A.M., 2021. Effect of some browse trees leaves on hematological parameters of yankasa lambs. Int. J. Health Pharm. Res. 6, 70-75.

Nwogor, U.A., Sandra, O., Uchenna, A., 2020. The effects of Allium sativum and Piper nigrum on the growth perfomance and packed cell volume of broiler chicks. Int.J. Anim. Sci. Tech. 4, 1-5. https://doi.org/10.11648/j. ijast.20200401.11

Nwogor, U.A., Uche, O.A., Ifeyinwa, E.C., Emmanuel, A.C., 2015. Effect of locally produced blood meal on growth performance and packed cell volume of broiler chicks. Am. J.Agric. For. 3, 105-108. https://doi.org/10.11648/j. ajaf.20150303.17

Onyishi, G.C., Oguine, C.C., Nwani, S.I., Aguzie, I.O., Nwani, CD., 2017. Haematological parameters dynamics of developing Gallus gallus domesticus. Anim. Res. Int. 14, 2769-2776.

Permadi, W., 2013. Peranan aromatase inhibitor dalam induksi ovulasi. Available at: http://pustaka.unpad. ac.id/wp-content/uploads/2016/02/PerananAromatase-Inhibitor_Cisral.pdf. [Date accesed: 18 March 2021]

Pomara, C., Barone, R., Marino Gammazza, A., Sangiorgi, C., Barone, F., Pitruzzella, A., Locorontondo, N., Gaudio, F.D., Salerno, M., Maglietta, F., Sarni, A.L., Felice, V.D., Cappello, F., Turillazzi, E., 2016. Effects of nandrolone stimulation on testosterone biosynthesis in leydig cells. J. Cell Physiol. 231, 1385-1391. https://doi. org/10.1002/jcp.25272

Prachayasittikul, V., Pingaew, R., Nantasenamat, C., Prachayasittikul, S., Ruchirawat, S., Prachayasittikul, V., 2014. Investigation of aromatase inhibitory activity of metal complexes of 8-hydroxyquinolineand uracil derivatives. Drug Des. Dev. Ther. 8, 1089-1096. https:// doi.org/10.2147/DDDT.S67300
Roselli, C.F. 2007. Brain aromatase: Roles in reproduction and neuroprotection. J Steroid Biochem. Mol. Biol. 106 143-150. https://doi.org/10.1016/j.jsbmb.2007.05.014

Saari, T.W., Schroeder, A.L., Ankley, G.T., Villeneuve, D.L. 2017. First-generation annotations for the fathead minnow (Pimephales promelas) genome.Environ. Toxicol. Chem. 36, 3436-3442. https://doi.org/10.1002/etc.3929

Sankako, M.K., Garcia, P.C., Piffer, R.C., Dallaqua, B., Damasceno, D.C., Pereira, O.C.M. 2012. Possible mechanism by which zinc protects the testicular function of rats exposed to cigarette smoke. Pharmacol. Rep.64, 15371546. https://doi.org/10.1016/S1734-1140(12)70951-9

Sauer, A.K., Hagmeyer, S., Grabrucker, A.M., 2016. Zinc Deficiency, In: Erkekoglu P., Kocel-Gumusel B. (Eds.), Nutritional deficiency. In Tech Open Science, Rijeka, pp. 23-46.

Souza, S.A., Held, A., Lu, W.J., Drouhard, B., Avila, B., LeyvaMontes, R., Hu, M., Miller, B.R., Ng, H.L., 2021. Mechanisms of allosteric and mixed mode aromatase inhibitors. RSC Chem. Biol. 2, 892-905. https://doi. org/10.1039/D1CB00046B

Standard Operating Procedure Bird Euthanasia (2016). Standard Operating Procedure (SOP) Bird Euthanasia, Comparative Medicine and Animal Resources Centre, Iowa State University.

Wang, L., Wang, W.X., 2014. Depuration of metals by the green-colored oyster Crassostrea sikamea. Environ. Toxicol. Chem. 33,2379-2385. https://doi.org/10.1002/ etc. 2695

Yuneldi, R.F., Airin, C.M., Saragih, H.T., Astuti, P., 2021a. Application of natural aromatase blocker towards the level of testosterone in rooster layer [Gallus gallus gallus (Linn., 1758)]. Key. Eng. Mater. 884 252-255. https://doi.org/10.4028/www.scientific. net/KEM.884.251

Yuneldi, R.F., Airin, C.M., Saragih, H.T. and Astuti, P. 2021b. Efficiency of testosterone administration on the performance of day old chick (DOC) layer: Cockscomb size, T3/T4 ratio, and histopathological description of bursa fabricius. In: Proceedings of the 2nd International Conference on Veterinary, Animal, and Environmental Sciences (ICVAES 2020). Aceh: Atlantis Press. pp. 3539. https://doi.org/10.2991/absr.k.210420.008

Yuneldi, R.F., Airin, C.M., Saragih, H.T., Astuti, P., 2021c. Profile of thyroid hormone in male layer chickens given by testosterone. IOP Conference Series: Earth and Environmental. 686, 012028. https://doi. org/10.1088/1755-1315/686/1/012028

Yuneldi, R.F., Astuti, P., Saragih, H.T.S., Airin, C.M., 2021d. Anadara granosa shell powder improves the metabolism, testosterone level, and sound frequency of Pelung chickens. Vet. World. 14, 1564-1571. https:// doi.org/10.14202/vetworld.2021.1564-1571

Yuneldi, R.F., Saraswati, T.R., Yuniwarti, E.Y.W., 2018. Profile of SGPT and SGOT on male rats (Rattus norvegicus) hyperglycemic after giving insulin leaf extract (Tithonia diversifolia). Biosaintifika J. Biol. Biol. Educ. 10, 519-525. https://doi.org/10.15294/biosaintifika. v10i3.5516

Zeryehun, T., Asrat, M., Amha, N., Urge, M., 2017. Effects of supplementation of different levels of garlic (Allium sativum) on selected blood profile and immunity of white leghorn chicken. Biotechnol. Anim. Husb. 33, 333-348. https://doi.org/10.2298/BAH1703333Z

Zhang, W., Wei, Y., Cao, X., Guo, K., Wang, Q., Xiao, X., Zhai, X., Wang, D., Huang, Z., 2021. Enzymatic preparation of Crassostrea oyster peptides and their promoting effect on male hormone production.J. Ethnopharmacol. 264, 1-10. https://doi.org/10.1016/j.jep.2020.113382 